\title{
Breast Non-Hodgkin Lymphoma
}

National Cancer Institute

\section{Source}

National Cancer Institute. Breast Non-Hodgkin Lymphoma. NCI Thesaurus. Code C5181.

A non-Hodgkin lymphoma that arises from the breast. There is no history of

extramammary breast non-Hodgkin lymphoma and ipsilateral axillary lymph node

involvement does not exclude the diagnosis of primary breast non-Hodgkin lymphoma.

Most patients present with a painless breast lump. The vast majority of cases are B-cell

non-Hodgkin lymphomas. Diffuse large B-cell lymphoma, follicular lymphoma, and

extranodal marg inal zone B-cell lymphoma of mucosa associated lymphoid tissue are

the most common types of primary non-Hodgkin lymphoma of the breast. 